International Journal of English Literature and Social Sciences
Vol-6, Issue-4; Jul-Aug, 2021

Peer-Reviewed Journal

\title{
Virtual Classroom Anxieties of Senior High School Teachers
}

\author{
Mark Alvin H. Abad ${ }^{1}$, Joanna Marie Franco ${ }^{2}$, Miguel B. Gutay Jr. ${ }^{3}$, Micah Angelica A. \\ Mapili $^{4}$, Jio Maryo G. Subaba ${ }^{5}$, Jocelyn B. Cruz ${ }^{6}$
}

\author{
${ }^{1}$ College of Management and Business Technology, Hospitality and Tourism Department, Nueva Ecija University of Science and \\ Technology, Philippines \\ ${ }^{2}$ ASKI Multi-Purpose Cooperative, Alalay Sa Kaunlaran (ASKI) Inc., Philippines \\ ${ }^{3}$ Mutual Benefit Association, Alalay Sa Kaunlaran (ASKI) Inc., Philippines \\ ${ }^{4}$ Senior High School Department, San Jose National High School, Philippines \\ ${ }^{5}$ Department of Education San Jose City, Nueva Ecija, Philippines \\ ${ }^{6}$ Dean, NEUST Graduate School, Philippines
}

Received: 14 Jun 2021; Received in revised form: 08 Jul 2021; Accepted: 14 Jul 2021; Available online: 24 Jul 2021

C2021 The Author(s). Published by Infogain Publication. This is an open access article under the CC BY license

(https://creativecommons.org/licenses/by/4.0/).

\begin{abstract}
The use of online education has increased dramatically during the previous decade. In academia, online learning and virtual classrooms have evolved from a unique experiment to a nearly universal teaching tool [1]. The Virtual Classroom Anxieties of Senior High School Teachers were investigated in this study. The research is descriptive-correlational. Teachers at San Jose City National High School in Nueva Ecija, Philippines, were polled using a survey questionnaire. The data were treated and analyzed using frequency counts, percentages, weighted mean, and correlational formulas. The study's findings revealed that the majority of the teachers who responded were female and in their forties. They enrolled in a Bachelor of Secondary Education program with an emphasis in English and non-major courses. Most of the respondents already have their units in a Master's degree and have a permanent position. English was ranked first in terms of subjects taught. In terms of psychological, behavioral, and emotional anxiety, the respondents did not feel anxious when teaching in a virtual classroom since most of them were not overworked and were properly compensated.
\end{abstract}

Keywords-Anxieties, online education, senior high school, teachers, virtual classroom.

\section{INTRODUCTION}

This school year, 2020-2021, will be considerably different from the previous school year that the teachers, are familiar with. This Pandemic that people are all currently experiencing has affected the teaching methods, and the researchers want to find out if teachers are suffering anxiety. This study focuses on the virtual classroom fears of Senior High School Science teachers. Lesson preparation and delivery are difficult for teachers who teach outside their area of specialization [2]. Senior high school teachers are currently confronted with a dilemma between 21 st-century teaching competencies and classroom fears. Teachers in senior high school should be able to relate their subject matter to their students' worlds, natural science, and social science, even if they already know and comprehend their subject matter well beyond and below what they are supposed to teach. Students frequently confront problems and difficulties in various courses, necessitating the search for the best techniques and means to tackle these issues, which can only be accomplished through the use of proper evaluation tools [3].

The K to 12 Reform (R.A. 10533) changed the landscape of teacher quality requirements in the Philippines as a 
result of this. A similar supportive focus on teacher quality - high-quality instructors who are appropriately qualified and prepared to fulfill the tasks and functions of $\mathrm{K}-12$ teachers - is required as part of the reform process. Many teaching opportunities in both public and private high schools had become available as a result of the additional two years of Senior High School. During this transition time, hired teachers are expected to teach a variety of subjects ranging from Core to Applied to Specialized, depending on the school's Track and Strands. One obvious issue that has arisen as a result of this structure is that some teachers have been assigned to teach courses outside of their area of expertise. Administrators were required to assign teachers to subjects that were the most closely related to their areas of expertise, such as English teachers teaching Filipino subjects. There are some subjects, such as applied and specialist subjects, where it is difficult to find a close fit. This development is unavoidable, as even countries that have already institutionalized K-12 are grappling with the issue of out-of-field educators [4]. Aside from out-of-field teachers, there are also teachers who are not Education graduates who have been hired. Many of these instructors come from the business world or higher education. Out-of-field instruction is a fact that many Senior High Schools must deal with, and it isn't going away anytime soon. To address the behavioral, psychological, and emotional concerns that these teachers may have in the classroom, further research is needed to better understand their condition and respond appropriately. It's not uncommon for teachers, especially those who are new to the profession, to be concerned about what might happen in the classroom. Students' behavior, the cleanliness of the environment, reports to be completed, information to be taught, and many other factors are all factors that instructors must consider when doing their tasks [5]. Teaching anxiety, according to Oral, can occur at any level of teaching, including during the internship stage. Furthermore, when comparing rookie teachers to experienced teachers, the incidence of worrisome incidents was higher. Finally, anxiety levels are higher during the first several months of teaching [6].

Having established that anxiety is something that is present in the classroom and it becomes imperative for causes to be identified, as a means to mitigate and regulate anxiety. Discipline problems often led to a high level of anxiety in teachers and that in some cases, a high level of anxiety by the teacher at the start of a lesson actually appears to be a cause of discipline problems. Classroom management becomes difficult if teachers are not able to strike a chord with the student they are teaching. One other major issue which may cause discomfort to the teacher is 'evaluation anxiety' [7]. Just as students find certain subjects to be difficult, teachers can find certain subjects to be difficult to learn and teach which causes anxiety [8].Virtual classroom anxiety can cause lower academic performance at the same time unsatisfactory teaching performance. Senior High Schools teachers should know their own weaknesses and strengths to be able to achieve a higher quality of education. In this regard, the researchers investigated if there were the presence of virtual classroom anxieties as to psychological, behavioral, and emotional among senior high schoolteachers in San Jose City National High School and if there were correlations of anxieties.

\section{METHODOLOGY}

The research design used in this study was descriptivecorrelational. This design was chosen because it allows for a more in-depth understanding of the virtual classroom worries of San Jose City National High School - Senior High School teachers. Questionnaires were used to gather information. The study describes and evaluates the characteristics of the entire group. This study is interested in existing circumstances or relationships, behaviors that are followed, processes that are felt without exerting any effort, and emerging tendencies [9]. A 4-point Likert Scale was used to assess the survey. A Likert scale is a type of rating scale that is used to evaluate people's ideas, attitudes, and behaviors [10]. In the current School Year, 2020-2021, 51 senior high school teachers from San Jose City National High School - Senior High School in the Division of San Jose City participated in the study. The data were treated using frequency, percentage, weighted mean, and correlational formulas by the researchers. The information gathered through the responses of the respondents in the questionnaire adapted from Naco (2015)'s previous study on "Competencies and Anxiety in Teaching Mathematics Among Elementary School Teachers in the K to 12 Curriculum in the Division of San Jose City" was used to support the discussions.

\section{RESULTS AND DISCUSSION}

This research focused on the socio-demographic profile of the senior high school teachers in terms of their age, sex, bachelor's degree, major, highest educational attainment, teaching position, employment status, subjects taught, number of working hours per day as a teacher in school, work experience; and monthly gross income. Moreover, the study also described the respondent's virtual classroom anxiety in terms of behavioral, psychological, and emotional. On a more specific note, the study determined the relationship between the socio-demographic profiles of the respondents to their virtual classroom anxiety.Fifty-one (51) senior high school teachers of San Jose City National 
High School - Senior High School during the School Year 2020-2021 were the respondents of the study.

The following were the significant findings of the study:

\section{Socio-Demographic Profile}

Age. The result showed that 3 or $5.88 \%$ of the respondents are 21-25 years old while 16 or $31.37 \%$ are $26-30$ years old. Further, 10 or $19.61 \%$ of the respondents are $31-35$ years old, 17 or $33.33 \%$ of them are $36-40$ years old, 3 or $5.88 \%$ are $41-45$ years old, and that 2 or $3.92 \%$ of them are 46-50 years old. The findings imply that many of the respondents were in the age bracket of 36-40 years old.

Sex. There are more females than males. The result showed that there were 22 or $43.10 \%$ were males and 29 or $56.90 \%$ were females.

Bachelor's Degree. There are 26 Education graduates among the 51 respondents, 25 are Bachelor of Secondary Education while the remaining 1 respondent was a Bachelor of Elementary Education degree holder and the remaining 25 respondents out-off 51 are non-education graduates. This implies that almost $50 \%$ of the total senior high school teacher are education graduates.

Bachelor's Degree Major. There are more than 7 or $13.73 \%$ English majors, 6 or $11.76 \%$ for both Filipino and Management majors while Science, Math and TLE majors are only 5 or $9.80 \%$, MAPEH and Economics majors got both 2 or $3.92 \%, 1$ or $1.96 \%$ for Computer Network Programming, Soil and Waste Management and Political Science major and lastly, there are 4 or $7.84 \%$ of the total population that have no majors. This result shows that English majors are dominated by the other majors because English subjects are Core subjects meaning English majors are much needed in senior high.

Highest Educational Attainment. 7 or $13.70 \%$ of the total population are Bachelor's Degree holders, 27 or $52.90 \%$ are with their Master's Degree units while 6 or $11.80 \%$ are already finished their Master's Degree. Among 51 respondents there are 10 or 19.60 who have their Doctorate Degree units and only 1 or $2.00 \%$ already graduated Doctorate Degree. It implies that there are many senior high school teachers who are still studying to enhance and develop their skills and knowledge.

Teaching Position. There are 15 or $29.40 \%$ Teacher I, 27 or $52.90 \%$ Teacher II, 7 or $13.70 \%$ Teacher III and 1 or $2.00 \%$ for both Master Teacher I and II respectively, meaning there are a lot of teachers are in lower positions than the higher ones.

Employment Status. Among 51 respondents there are 45 or $88.20 \%$ permanent, 5 or $9.80 \%$ probationary, and 1 or $2.00 \%$ substitute, this result implies that there are still senior high school teachers that are not yet permanent in their positions.

Subject Taught. Among the 10 subjects offered to senior high school for this school year, English subjects were being taught by 18 teachers, meaning English subjects are being taught in all senior high school learners as one of their core subjects.

A number of Working Hours Per day. 13 or $25.50 \%$ of the senior high school teacher are working 5-6 hours daily, 36 or $70.60 \%$ worked $7-8$ hours daily and lastly, 2 or $3.90 \%$ are working 9-10 daily, meaning, that teachers are really busy in their work.

Work Experience Prior to their Present Job. Out-off of 51 senior high school teachers, 41 or $80.40 \%$ of them are also teachers before they decided to apply as a senior high teacher and the remaining 10 or $19.6 \%$ are working in the different industries before they become teachers.

Monthly Gross Income. There is 1 or $2.00 \%$ who has $\mathrm{PhP}$ 10,000 below monthly gross income, 4 or 7.80 have $\mathrm{PhP}$ 10,001 - PhP 20,000, 43 or $84.30 \%$ have $\mathrm{PhP} 20.001-$ $\mathrm{PhP} 30,000$ monthly gross income, 1 or $2.00 \%$ has $\mathrm{PhP}$ $30,001-\mathrm{PhP} 40,000$ and 2 or $3.90 \%$ have a monthly gross income of $\mathrm{PhP} 40,001$ up.

\section{Teaching Anxieties of Respondents in Classroom}

Among the three anxieties, Psychological obtained the highest weighted mean 1.74 and is described as "Not Anxious" while Emotional Anxiety obtained the lowest weighted mean of 1.58 and is described as "Not Anxious". All anxieties were described as "Not Anxious as perceived by the respondents.

\section{Relationship between the socio-demographic profiles of the respondents to their Classroom Anxieties}

All socio-demographic profiles of the respondents in terms of their age, sex, bachelor's degree, major, highest educational attainment, teaching position, employment status, subjects taught, number of working hours per day as a teacher in school, work experience; and monthly gross income were found not correlated with the respondents' Classroom Anxieties.

\section{Proposed Intervention Activities}

Since the senior high school teachers were found out that in general, they are not anxious when teaching in the virtual classroom. Teachers were confident in facilitating learning in front of the class. To sustain this self-esteem of teachers, school heads should regularly conduct Classroom Teaching Observation or COT. This observation was already included in Result- Based Performance Management System (RPMS) Tool for teachers or the evaluation for teachers' performance. The school may 
continue sending the teachers to division, regional seminars, and national training on anxieties, inset seminars, and Learning Action Cell (LAC) sessions to maintain and improve the behavioral, psychological, and emotional health of all the teachers.

\section{CONCLUSIONS AND RECOMMENDATIONS}

The majority of the teacher-respondents were female and in their middle age. They took a Bachelor of Secondary Education major in English and non-major courses. The respondents already have their units in Master's Degree and in a permanent position and already teachers before they enter senior high. In terms of the subject taught, English got the first rank. Almost half of them did not have a working overload and were well-compensated. The respondents were not anxious when teaching in a virtual classroom in terms of psychological, behavioral, and emotional. Teacher socio-demographic factors were not significantly related to their virtual classroom teaching anxieties.Based on the results of the study, it can be proposed that the conduct of seminars and training on classroom anxieties targeted to a specific niche of senior high school teachers be held and that teachers may be encouraged to attend workshops and conferences on how to cope up different types of anxieties. Based on the results of the study and conclusions drawn, these recommendations are offered: The senior high school teachers were ready to engage in virtual classroom teaching [11]. Since the majority of the teacherrespondents already have their units in Master's Degree, they are encouraged to align and finishing their Master's Degree up to doctoral degree programs. This will sustain their competence [12] in teaching especially in learning and reflection, be updated to the new methods and other capacity-building activities strategies suitable for the senior high school students [13] at the same time it will lead to promotion and higher compensation.

\section{REFERENCES}

[1] Simon, Edwin (2012). The Impact of Online Teaching on Higher Education Faculty's Professional Identity and the Role of Technology: The Coming of Age of the Virtual Teacher.

https://www.colorado.edu/atlas/sites/default/files/attachedfiles/the_impact_of_online_teaching_on_higher_education faculty.pdf

[2] Mizzi, D. (2013). The Challenges Faced By Science Teachers When Teaching Outside Their Specific Science Specialism. Acta Didactica Napocensis, Vol. 6 No. 4.
[3] Naco, P. L. (2015) Competencies and Anxiety in Teaching Mathematics Among Elementary School Teachers in the $\mathrm{k}$ to 12 Curriculumin the Division of San Jose City

[4] Hobbs, L. (2015, April 13). Too many teachers teaching outside their area of expertise. Retrieved from The Conversation: https://theconversation.com/too-manyteachers-teaching-outside-their-area-of-expertise-39688

[5] Oral (2012). Understanding the Causes of Anxiety and Coping Strategies of Student- teachers during Their internship: A Phenomenological Study.

[6] Sammephet \& Wanpet, (2013). Understanding the Causes of Anxiety and Coping Strategies of Student- teachers during Their Internship: A Phenomenological Study.

[7] Nabhani, M., Bahous, R., \& Sabra, H. (2015). Teachers' and Supervisors' Views on Clinical Supervision: A Case Study from Lebanon. The Educational Forum, Vol 79.

[8] Beilock S. \& Levine S., (2011).Math Anxiety, Working Memory and Math Achievement in Early Elementary School

[9] Bailey, K. (2001). Teacher Preparation and Development https://doi.org/10.2307/3588439

[10] Bhandari P. (2020). Designing and Analyzing Likert scale. https://www.scribbr.com/methodology/likert-scale/

[11] Mina, J.C., Subia, G.S.,Barlis, P.T., Tuliao, R.C. and Pastorfide, P.M. (2020). Inclinations of Engineering and Marketing Management Students to Engage in Online Learning Technology Amidst the COVID-19 Pandemic. Technology Reports of Kansai University, ISSN: 04532198, Volume 62, Issue 09

[12] Marcos, M., Subia, G., Ermita, P. (2020). Entry Competencies and Performance in Mathematics of FirstYear Engineering Students in State Universities in Region 3. Test Engineering and Management. ISSN: 0193-4120 Page No. 10148 - 10158.

[13] Subia, G., Marcos, M., Valdez, A., Pascual, L. \&Liangco, M.(2020). Cognitive Levels as Measure of Higher-Order Thinking Skills in Senior High School Mathematics of Science, Technology, Engineering, and Mathematics (STEM) Graduates. Technology Reports of Kansai University. Volume 62, Issue 3, pp 261-268 